УДК 551.311.231:553.81

\title{
Особенности строения и состава коры выветривания на кимберлитовых породах
}

\author{
Н.Н. Зинчук \\ Западно-Якутский научный центр Академии наук Республики Саха \\ (Якутия). 678170, Мирный, ул. Ленина, 4/1 \\ E-mail: nnzinchuk@rambler.ru \\ (Статья поступила в редакцию 2 октября 2015 г.)
}

На основании комплексных исследований приведены закономерности минералого-геохимического изменения кимберлитов в гипергенных условиях. В наиболее зрелых профилях коры выветривания кимберлитов существенным преобразованиям подвергаются как породообразующие, так и более устойчивые первичные минералы. Существенно уменьшается в верхах профилей количество оливина, пироксенов, пиропа и возрастает роль пикроильменита. В нижних частях профилей выветривания этого типа доминирует серпентин, представленный слоями структурного типа А и В. Для слоев новообразованного типа А вначале характерна округлая глобулярная форма, которая наблюдается на зернах других более устойчивых минералов. На ранних этапах выветривания кимберлитов изменение серпентина связано с его перекристаллизацией, сопровождающейся политипными превращениями. Одновременно с этим слоистые минералы триоктаэдрического типа либо разлагаются ( $\mathrm{Mg}-$ и $\mathrm{Fe}-\mathrm{Mg}$-хлориты), либо частично преобразуются в диоктаэдрические разности (флогопит в гидрослюду и др.). Эти процессы обусловливают значительное повышение пористости и проницаемости первичных пород, что определяет последовательное увеличение в их объеме открытой поверхности, контактирующей с пневматолитово-гидротермальными флюидами, и скорости дренирования последними выветривавшихся горизонтов. Минеральный состав новообразований и распределение по элювиальным профилям значений $\mathrm{pH}$ и Eh позволяют утверждать, что рассматриваемая стадия выветривания кимберлитов соответствует щелочному типу. Рассмотренные элювиальные профили можно отнести к типу остаточных локальных кор выветривания, находящихся на стадии начальной гидратации исходных минералов и выщелачивания наименее устойчивых компонентов.

Ключевые слова: коры выветривания, кимберлиты, минералого-геохимические изменения, пневматолитово-гидротермальные флюиды, триоктаэдрические и диоктаэдрические минераль.

DOI: $10.17072 /$ psu.geol.30.60

На древних платформах мира, в пределах которых установлен кимберлитовый магматизм, выделяются как крупные, так и относительно малые по размерам кимберлитовые трубки [2-5, 24, 25, 29], причем на многих из них развита остаточная кора выветривания [6-19, 22, 27-32]. Проведенные нами комплексные исследования и анализ имеющегося материала по геолого-вещественным особенностям кор выветривания (КВ) на кимберлитовых трубках Сибирской платформы (СП) пока- 
зали, что интенсивно гипергенно химически переработанные кимберлиты отмечаются только в некоторых алмазоносных районах.

Примером развития остаточной КВ кимберлитов могут быть известные в Малоботуобинском алмазоносном районе диатремы имени ХХШ сьезда КПСС, Дачная, Таёжная, Амакинская, Интернациональная и Мир. Первые данные о геологическом строении и вещественном составе КВ кимберлитов в этом районе были получены исследователями $[27,30]$ для трубки имени ХХШ сьезда КПСС (рис.1),

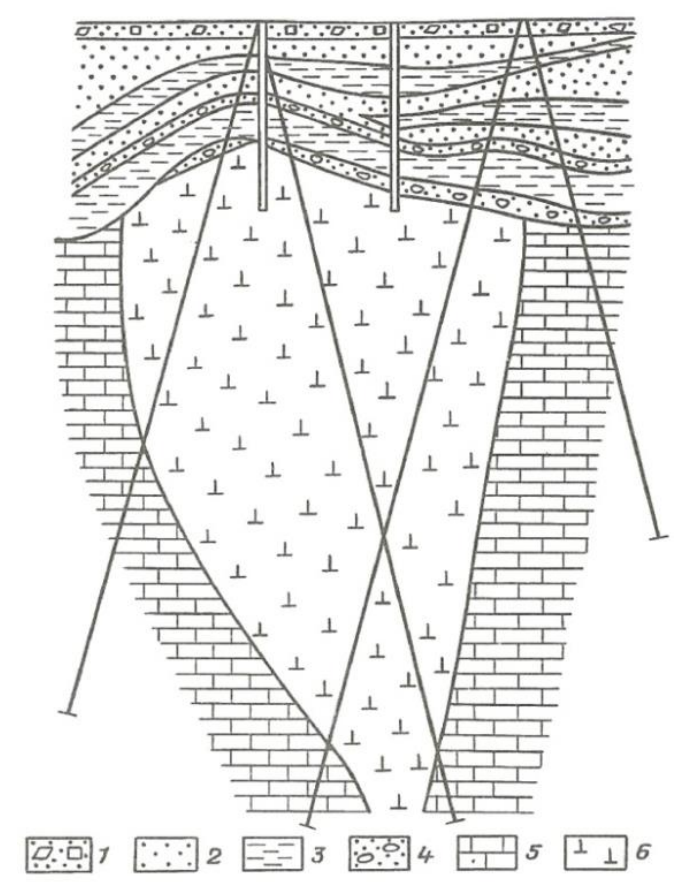

Рис. 1. Геологический разрез кимберлитовой трубки имени ХХШ съезда КПСС: 1 - делювиальный слой; 2-4 - отложения нижней юры: 2 - песчаники, 3 - алевролиты, 4 - конгломераты; 5 - терригенно-карбонатные породы устькутского яруса нижнего ордовика; 6-кимберлить

отметившими по её разрезу более глубокую химическую переработку пород, чем в других диатремах СП [1, 20-28]. В последние годы вскрыты новые разрезы (скв.А-63К и шахта 102), позволившие нам провести комплексные исследования минерального состава и структурных особенностей кимберлитовых пород в процессе выветривания (рис.2, а-б; рис.3, а; таблица).

Исходные, подвергшиеся выветриванию породы этой диатремы представлены серой и голубовато-серой плотной кимберлитовой брекчией (скв.А-63К, глубина 32,9 м и ниже; шахта 102, глубина 30 м и ниже). Преобладающая масса породы сложена агрегатами кальцита и серпентина с мелкими рассеянными выделениями магнетита. Количество обломочного материала редко превышает $25 \%$ объема породы. Участками увеличено (до 30\%) количество псевдоморфоз по вкрапленникам оливина. Процесс выветривания кимберлитов приводит к резкому увеличению их общей пористости (от 7,6 до 48,7\%) и уменьшению средней плотности (от 2,92 до $\left.1,50 \mathrm{r} / \mathrm{cm}^{3}\right)$. При этом возрастает трещиноватость пород и содержание пелитовых частиц (рис. 2, а-б). Соответственно уменьшается роль обломков пород, что также приводит к существенному изменению физических и физико-механических свойств кимберлитов вверх по разрезу.

В легкой фракции преобладают серые, серовато-бурые глинистые и глинистожелезистые агрегаты, практически не разрушающиеся при дезинтеграции пород и трудно определяемые в иммерсионных препаратах. Присутствуют также обломки кварца, покрытые землистыми примазками и «рубашками» вторичных продуктов изменения кимберлитов. Во фракции крупнее 0,1 мм отмечены выделения халцедона и зерна плагиоклазов, связанные в основном с разрушением обломков различных пород (траппов, терригеннокарбонатных образований и др.), содержащихся в кимберлитах диатремы. В легкой фракции пород нижних горизонтов (глубины ниже 30 м) встречается много слюды. Уже в нижних частях зоны дезинтеграции чешуйки флогопита приобретают зеленоватую пятнистую окраску, что связано с замещением его хлоритом.

Среди первичных минералов тяжелой фракиии образований рассматриваемой КВ преобладают ильменит (в основном пикроильменит) и гранаты (рис. 2). Последние встречаются в классах крупнее 
0,1 мм, тогда как пикроильменит доминирует в тяжелом концентрате фракции 0,10,05 мм. Количество пиропа уменьшается в процессе выветривания [8, 15, 29]. Вследствие этого возрастает роль более устойчивого в гипергенных условиях пикроильменита.
В резко подчиненном количестве отмечены хромит, хромдиопсид, турмалин, циркон, дистен, рутил, сфен и др. Аутигенный комплекс минералов тяжелой фракции чаще всего обогащен гидроксидами железа (гётит), гематитом и сидеритом (рис.2).

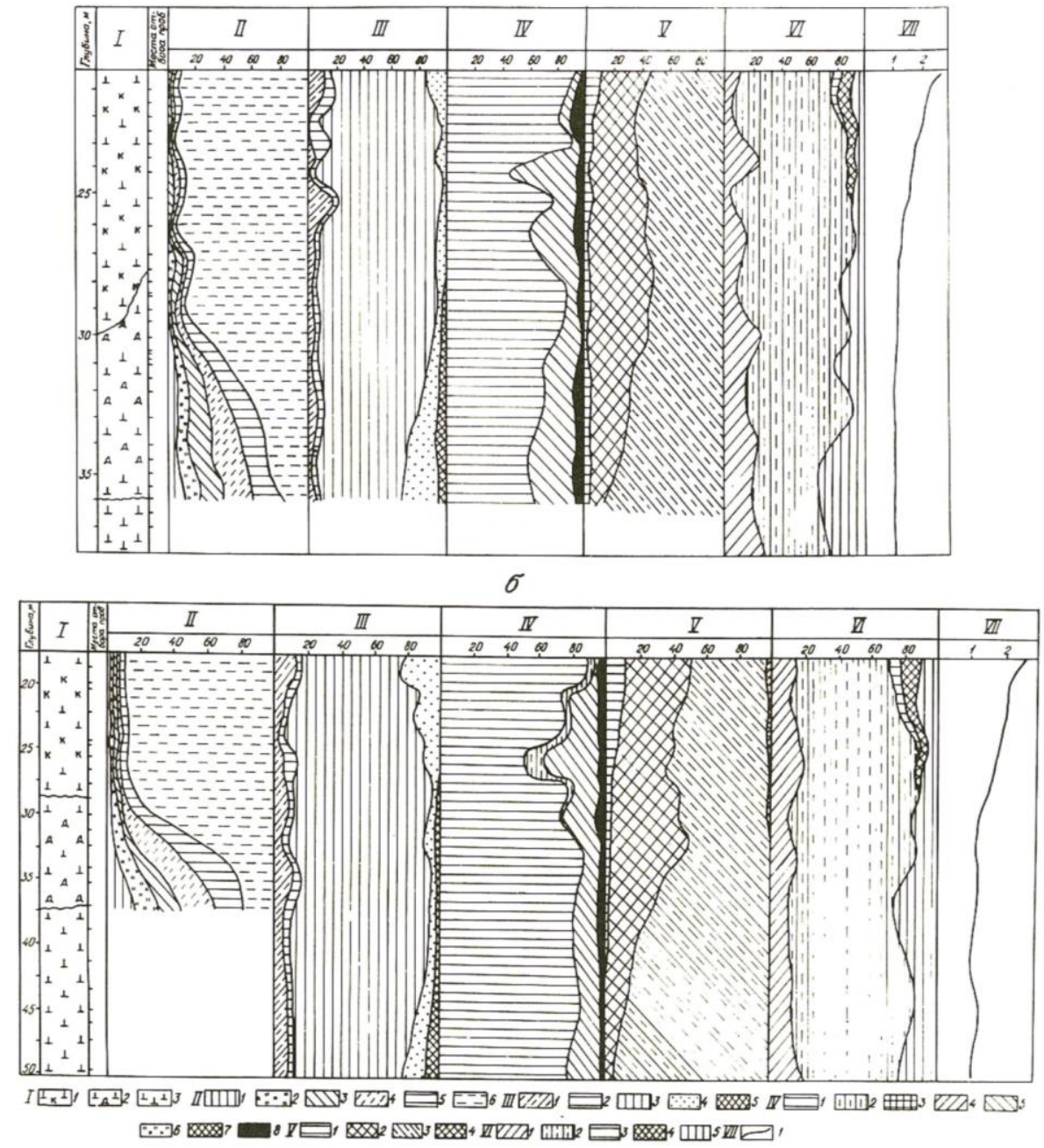

Рис. 2. Литологические разрезы коры выветривания кимберлитов трубки имени ХХІІІ съезда КПСС: $а$ - шахта 102; б - А-63К. І. Литологическая колонка: 1 - выветрелье образования; 2 дезинтегрированные породы; 3 - плотные кимберлиты. II. Гранулометрический состав (размеры фракиий в мм): 1 - 1,0-0,5; 2 - 0,5-0,25; 3-0,25-0,1; 4-0,1-0,05; 5-0,05-0,01; 6-мельче 0,01 мм. III. Состав легкой части фракичи 0,1-0,05 мм: 1 - квари; 2 - полевые шпаты; 3 слюдисто-глинистые и глинисто-железистые агрегаты; 4 - обломки различных пород; 5 слюды. IV. Состав первичных минералов тяжелой части фракиии 0,1-0,05 мм: 1 - неизмененный ильменит и магнетит; 2 - измененные рудные минераль;; 3 - неустойчивые минераль биотит, флогопит, пироксены и амфиболь;; 4 - умеренно устойчивые минералы - группа эпидота и апатит; 5 - гранаты; 6 - турмалин; 7 - ииркон; 8 - другие весьма устойчивые минеральг. V. Аутигенные минералы тяжелой части фракции 0,1-0,05 мм: 1 - пирит; 2 - сидерит; 3 гидроксиды железа (гётит, гидрогетит, гематит; 4 - барит. VI. Минеральный состав фракции мельче 0,001 мм: 1 - гидрослюда; 2 - монтмориллонит и монтмориллонитгидрослюдистые смешанослойные образования; 3 - каолинит; 4 -метагаллуазит; 5 -хлорит. VII. Отношение интенсивностей межплоскостных расстояний (d) со значением 10 и 5 А́ на дифрактограммах 

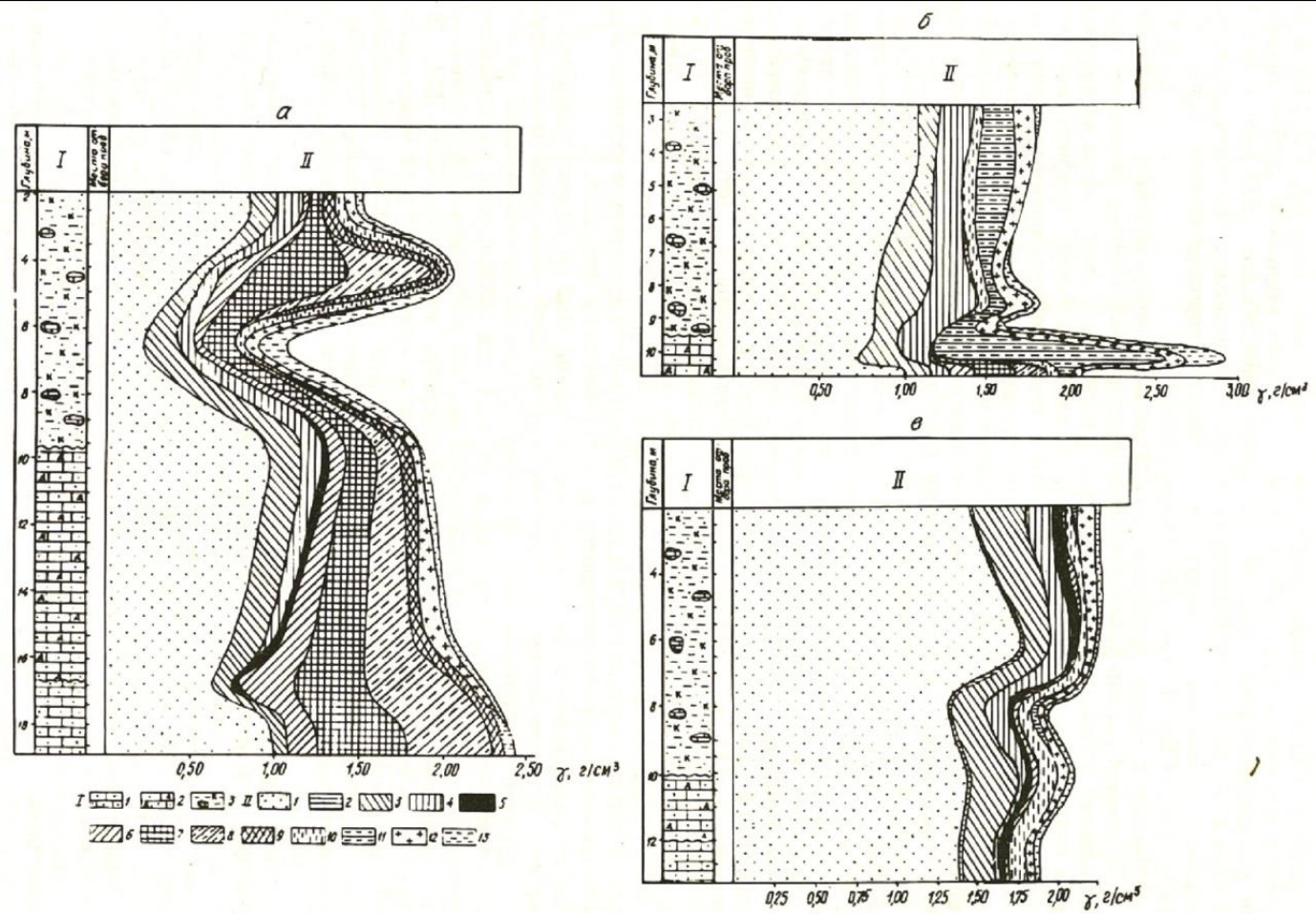

Рис. 3. Геохимические диаграммы коры выветривания кимберлитов трубок имени ХХШ сьезда КПСС (а), Дачная (б), Таежная (в). І. Литологическая колонка: 1 - плотные кимберлиты, 2 дезинтегрированные породыl, 3 - выветрелье кимберлиты. II. Оксиды: 1 - $\mathrm{SiO}_{2} ; 2$ - $\mathrm{TiO}_{2} ; 3$ $\mathrm{Al}_{2} \mathrm{O}_{3} ; 4-\mathrm{Fe}_{2} \mathrm{O}_{3} ; 5-\mathrm{FeO} ; 6-\mathrm{MgO} ; 7-\mathrm{CaO} ; 8-\mathrm{CO}_{2} ; 9-\mathrm{MnO}_{3} \mathrm{Cr}_{2} \mathrm{O}_{3}+\mathrm{NiO}+\mathrm{CoO} ; 10-\mathrm{Na}_{2} \mathrm{O}$ $+\mathrm{K} 2 \mathrm{O} ; 11-\mathrm{SO}_{3}+\mathrm{P}_{2} \mathrm{O}_{5}+\mathrm{F}+$ n.n.n.; $12-\mathrm{H}_{2} \mathrm{O}^{+} ; 13-\mathrm{H}_{2} \mathrm{O}^{-} ; 14-\mathrm{H}_{2} \mathrm{O}$ (общ.)

Содержание барита, концентрирующегося в классе 0,25-0,1 мм, редко превышает 10-15\%. Преобладающими породообразующими минералами плотных материнских пород являются пластинчатые серпентины, структура которых состоит из слоев типа А и В $[12,13,19]$. Ассоциирует серпентин в таких породах с гидрослюдой, монтмориллонит-гидрослюдистой смешанослойной фазой, хлоритом, вермикулитом и монтмориллонитом. Гидрослюда связана в основном с диоктаэдризацией флогопита и наследует свойственный последнему политип $1 \mathrm{M}$.

Выше по разрезу (скв.А-63К, глубина 22,2-32,9 м; шахта 102, глубина 25-30 м) отмечено дальнейшее усиление трещиноватости пород. Трещины нередко выполнены грязно-бурыми (местами до серовато-черных) вторичными образованиями. Отдельные прослои сложены сероцветными глинистыми образованиями с большим количеством мелких (мельче 0,1 мм) выделений гидроксидов железа и сидерита (рис.2).
Эти минералы иногда концентрируются в отдельных прослоях, образуя более темные участки. Сильная изменчивость свойственна и различным включениям этой части разреза. Иногда среди сильно измененных (до глинистого состояния) образований встречаются единичные слабо измененные псевдоморфозы серпентина.

Содержание диоктаэдрической гидрослюды здесь резко возрастает. Значительно увеличивается количество монтмориллонита, причем вверх по разрезу он становится более поликатионным, т. к. в составе лабильных межслоевых продуктов относительно возрастает роль $\mathrm{Na}$.

Судя по значению $b(8,93 \tilde{\AA})$, в октаэдрических сетках его структуры присутствуют главным образом Al и частично $\mathrm{Fe}^{3+}$. По всей изучаемой толще монтмориллонит ассоциирует с переменной примесью монтмориллонит-гидрослюдистой смешанослойной фазы, которой здесь свойственна тенденция к упорядоченности, хотя к верхам усиливаются явные элементы разупорядоченности структуры 
$[12,13]$.

Электронографическая характеристика фракции мельче 0,001 мм образиов из образований коры выветривания трубки имени ХХШ съезда КПСС (аналитик 3.В. Врублевская, ИГЕМ РАН)

\begin{tabular}{|c|c|c|c|c|}
\hline $\begin{array}{c}\text { Место } \\
\text { отбора } \\
\text { проб }\end{array}$ & $\begin{array}{l}\text { Глу- } \\
\text { бина } \\
\text { отбо- } \\
\text { ра, },\end{array}$ & $\begin{array}{c}\text { Литологические типы пород и } \\
\text { их цвет }\end{array}$ & $\begin{array}{c}\text { Глинистые минера- } \\
\text { лы, их политипные } \\
\text { модификации, сте- } \\
\text { пень совершенства } \\
\text { структуры, значе- } \\
\text { ние параметра } b, \AA \text {, }\end{array}$ & $\begin{array}{l}\text { Минералы- } \\
\text { примеси }\end{array}$ \\
\hline $\begin{array}{l}\text { Скв.А- } \\
63 К\end{array}$ & $\begin{array}{l}17,9 \\
18,8 \\
19,7 \\
22,2 \\
37,1 \\
49,0\end{array}$ & $\begin{array}{l}\text { Глинистые грязно-коричневые } \\
\text { образования } \\
\text { Глинистые желто-коричневые об- } \\
\text { разования } \\
\text { Глинистые темно-коричневые об- } \\
\text { разования } \\
\text { Глинистые желто-коричневые об- } \\
\text { разования с обломками пород } \\
\text { Кимберлит слабо выветрелый го- } \\
\text { лубовато-серый } \\
\text { Кимберлит очень плотный серый, } \\
\text { участками голубовато-серый }\end{array}$ & $\begin{array}{l}\text { сс }(9,00), \text { три-сс }(9,19) \\
\text { сл } 1 \mathrm{M}(\text { унн;9,00),три- } \\
\text { сс }(9,19) \\
\text { сл } 1 \mathrm{M}(\text { унн;9,00),три- } \\
\text { сс }(9,19) \\
\text { три-хл- } \delta^{\prime}(\sigma ; 9,22), \text { сл } \\
(б ; 9,00) \\
\text { три-сс }(9,22), \text { сс } \\
(9,00) \\
\text { три-сс }(б ; 9,15)\end{array}$ & $\begin{array}{l}\text { клц,сд,кв } \\
\text { клц,сд,гт } \\
\text { клц,сд,гт } \\
\text { клц,гт,сд } \\
\text { клц,дл } \\
\text { клц, дл }\end{array}$ \\
\hline $\begin{array}{l}\text { Шахта- } \\
102\end{array}$ & $\begin{array}{l}21,0 \\
22,0 \\
23,0 \\
25,0 \\
28,0 \\
30,0 \\
36,0\end{array}$ & $\begin{array}{l}\text { Глинистые зеленовато-серые об- } \\
\text { разования } \\
\text { Глинистые темно-серые породы с } \\
\text { прожилками желтовато-серых но- } \\
\text { вообразований } \\
\text { Глинистые зеленовато-серые об- } \\
\text { разования с обломками кимбер- } \\
\text { литов } \\
\text { Кимберлит выветрелый рыхлый } \\
\text { ожелезненный } \\
\text { Кимберлит выветрелый грязно- } \\
\text { серый до коричневого } \\
\text { Кимберлит слабо выветрелый го- } \\
\text { лубовато-серый } \\
\text { Кимберлит очень плотный голу- } \\
\text { бовато-серый }\end{array}$ & 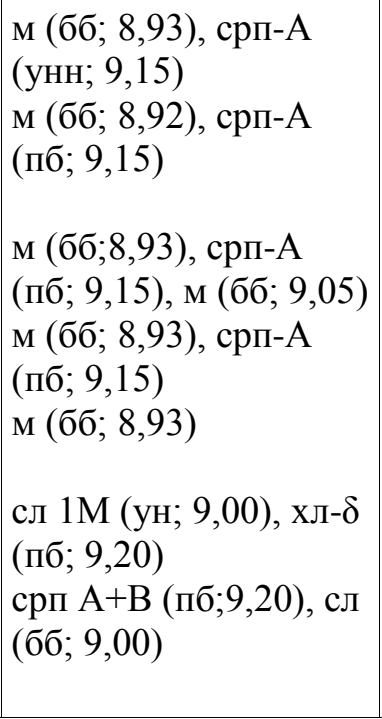 & $\begin{array}{l}\text { кв,гт } \\
\text { клц, кв } \\
\text { клц,сд,Мгт,Гт } \\
\text { мгт,сд,клц,ГМ,гт } \\
\text { мГт,сд,Гт,ГМ,Клц } \\
\text { сд; клц } \\
\text { клц,дл,сд }\end{array}$ \\
\hline
\end{tabular}

Примечания. Минералы: сл - гидрослюда, кл - каолинит, м - монтмориллонит, хл - хлорит, срп - серпентин, сc - неидентифицированный слоистый силикат, кв - кварц, клц - кальцит, дл - доломит, мгт - магнетит, гм - гематит, гт - гётит, сд - сидерит, три - триоктаэдрическая, ди - диоктаэдрическая разновидности. Политипные модификации: $1 \mathrm{M}$ - однослойной, $\delta$ и $\delta^{\prime}-$ хлорита, А и В - серпентина. Степень совершенства структуры: у - упорядоченная, ун - упорядоченная с некоторыми нарушениями, унн - упорядоченная с существенными нарушениями, пб - полубеспорядочная, б - беспорядочная, бб - полностью беспорядочная. Минералы приводятся в порядке убывания, цифры в скобках - величины $b$ в $\check{\text { A. }}$

В этой части разреза присутствует более существенная, чем в неизмененной толще кимберлитов, примесь $\mathrm{Fe}-\mathrm{Mg}$ или близкого к $\mathrm{Mg}$ типу хлорита, представленного за счет частичной деградации смесью разностей как с нормальной, так и с дефектной структурами. В ассоциации с ними отмечается примесь серпентина, представленного структурным типом А. Это сопровождается уменьшением его па- 
раметра $b$ (с 9,20 до 9,15 Ӑ) вследствие повышения в структуре роли катионов с меньшим ионным радиусом $\left(\mathrm{Fe}^{3+}\right)$. Судя по появлению в этой зоне (в прослоях с невысоким содержанием хлорита) на кривых ДТА дериватограмм интенсивного эндоэффекта при температуре $540-560^{\circ} \mathrm{C}$ и эндоэффекта при $900-910^{\circ} \mathrm{C}$, а также сохранению на дифрактограммах слабых рефлексов, кратных 7,15 А, после обработки образцов теплой $\mathrm{HCl}$, в этих продуктах выветривания есть примесь каолинита.

Самые верхние горизонты КВ (скв.А63К, глубина 18-22 м; шахта 102, глубина 21-25 м) сложены желтовато-коричневыми и грязно-бурыми образованиями, лишенными структурно-текстурных особенностей материнских пород. Реликты различных включений фиксируются лишь по изменению окраски на фоне общей массы породы. Довольно неравномерное распределение в породах этого интервала гидроксидов железа приводит к чередованию более темных (до черных) глинистых образований с более светлыми (зеленоватои желтовато-серыми). В продуктах выветривания (рис.2, а, б) содержится в основном монтмориллонит, ассоциирующий обычно с неупорядоченной монтмориллонит-гидрослюдистой смешанослойной фазой, в межслоевых промежутках которой преобладают $\mathrm{Mg}$ и Са. Значительно увеличивается здесь и отношение интенсивностей рефлексов 10 и 5 Ӓ на дифрактограммах, что указывает на последовательное изменение совершенства структуры и химизма слюдистых минералов. Соответственно, на кривых ИК-спектров образований самых верхов зоны сохраняются полосы поглощения деформационных колебаний $\mathrm{Si}-\mathrm{O}-\mathrm{Al}^{\mathrm{V} 1}$-связи с частотой 525 $530 \mathrm{~cm}^{-1}$ после прокаливания образцов при $600^{\circ} \mathrm{C}$, которые исчезают в её низах. Это свидетельствует об увеличении вверх по разрезу содержания Al в структуре трехэтажных минералов разбухающего типа. Отметим, что серпентин сохраняется вплоть до самых верхних частей разреза, а содержание каолинита практически не увеличивается. Иногда отмечается примесь сидерита (рефлекс 2,79 Ӑ). Последовательное увеличение по профилю выветривания общей пористости пород приводит к существенному снижению гигроскопической и естественной влажности (соответственно с 11,09 до 8,8 и с 50,55 до $21,64 \%$ ), хотя максимальная молекулярная влагоемкость при этом несколько повышается (от 20,09 до 31,94\%). Возрастание вверх содержаний пелитовой составляющей и образование собственно глинистых пород обусловливают соответственное изменение пластичности, прочности на сжатие, сопротивление сдвигу, а также скорости прохождения упругих волн.

Распределение продуктов выветривания по разрезам, вскрывшим различные горизонты КВ кимберлитов трубки имени ХХШ сьезда КПСС, непосредственно отражает некоторые различия их геохимической характеристики (рис.3, а). Так, для разреза скв.А-63К характерна довольно высокая подвижность главнейших породообразующих элементов. Наибольшей изменчивостью характеризуются $\mathrm{Fe}_{2} \mathrm{O}_{3}$, $\mathrm{Al}_{2} \mathrm{O}_{3}, \mathrm{TiO}_{2}, \mathrm{MgO}$ и $\mathrm{CaO}$. Перепады концентраций остальных компонентов обычно не превышают первые десятки процентов. В суммарном балансе вещества по разрезу скв.А-63К наиболее высокой подвижностью и способностью к выносу характеризуются $\mathrm{CaO}$ (от 0,4796 до 0,0841

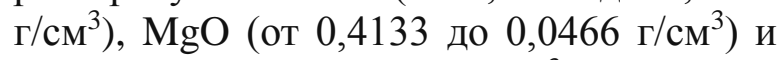
$\mathrm{CO}_{2}$ (от 0,5520 до $0,0523 \mathrm{r} / \mathrm{cm}^{3}$ ), что связано с растворением (таблица; рис.4) при выветривании отдельных компонентов ультраосновной породы (кальцита, хлорита и частично серпентина). Это обусловливает выпадение новых фаз, отличных по химическому составу от исходных пород, и удаление от пород продуктов реакции. Предпочтительная тенденция к накоплению свойственна следующим компонен-

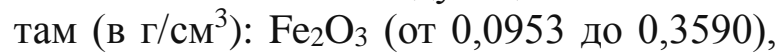
$\mathrm{TiO}_{2}$ (от 0,0112 до 0,0544 ), $\mathrm{Al}_{2} \mathrm{O}_{3}$ (от 0,0742 до 0,2627 ) и $\mathrm{SiO}_{2}$ (от 0,4796 до 0,5374 ). Малые элементы обычно проявляют довольно четкую линейную тенденцию к направленной подвижности вверх по раз- 
резу. Увеличение концентраций характерно для $\mathrm{Sc}, \mathrm{Ga}, \mathrm{Mn}, \mathrm{Nb}, \mathrm{V}, \mathrm{Cu}, \mathrm{Zr}, \mathrm{Co}, \mathrm{Cr}$ и La. Тенденцией к выносу обладают $\mathrm{Pb}$ и Cs. Отмечен максимум содержания в средних частях разреза $\mathrm{Be}, \mathrm{Pb}, \mathrm{Ni}, \mathrm{Zn}$ и $\mathrm{Sr}$. Ассоциативный анализ этих пород $[6,31]$ позволяет выделить следующие парагенетические ассоциации: $\mathrm{Be}-\mathrm{Sc}-\mathrm{Mg}-\mathrm{Cu}-$ $\mathrm{V}-\mathrm{Cr}-\mathrm{Co}-\mathrm{Zr}-\mathrm{Nb}-\mathrm{Mn}$ и $\mathrm{Zn}-\mathrm{Ni}$. Для остальных элементов характерна относительная независимость поведения в процессе корообразования. Несколько иная геохимическая характеристика наблюдается и в разрезе центральной части рассматриваемой диатремы, вскрытой шахтой 102. Для этого профиля также свойственна значительная подвижность большинства компонентов, однако в ряде интервалов резко увеличивается содержание отдельных оксидов. Подвергшиеся выветриванию кимберлиты данного разреза (глубины ниже 30 м) характеризуются здесь значительной концентрацией (в г/ $\left.\mathrm{cm}^{3}\right): \quad \mathrm{SiO}_{2} \quad(0,4011-0,4022), \quad \mathrm{MgO}$ (до 0,3017), $\mathrm{CaO} \quad(0,6011-0,6055)$ и $\mathrm{CO}_{2}$ (0,4740-0,4796). В процессе выветривания происходит перераспределение (таблица) практически всех породообразующих компонентов. Интенсивно выносятся из кимберлитов данного профиля (в $\left.г / \mathrm{cm}^{3}\right)$ $\mathrm{CaO}$ (до 0,0474), $\mathrm{MgO}$ (до 0,0351) и $\mathrm{CO}_{2}$ (до 0,0693). В общем балансе вещества по профилю выветривания тенденцию к накоплению показывают следующие оксиды (в $\left.г / \mathrm{cm}^{3}\right)$ : $\mathrm{FeO}$ (от 0,0358 до 0,1812 ), $\mathrm{Al}_{2} \mathrm{O}_{3}$ (от 0,0464 до 0,2943), $\mathrm{Fe}_{2} \mathrm{O}_{3}$ (от 0,0906 до 0,2528 ) и $\mathrm{SiO}_{2}$ (до 0,5670). Значительно накапливаются также $\mathrm{TiO}_{2}$, $\mathrm{Cr}_{2} \mathrm{O}_{3}, \mathrm{MnO}$ и $\mathrm{K}_{2} \mathrm{O}[6,12]$. Среди акцессорных элементов повышаются концентрации Mo, Nb, V и La. B средних частях этого профиля наблюдаются положительные аномалии содержания $\mathrm{Ga}$ и Со. Установлены следующие устойчивые парагенетические ассоциации: $\mathrm{Cu}-\mathrm{Nb}-\mathrm{Pb}-\mathrm{Ga}$ $-\mathrm{Sc}, \mathrm{Co}-\mathrm{Cr}-\mathrm{Zn}-\mathrm{Pb}-(\mathrm{Sr}$ ?), $\mathrm{Be}-\mathrm{Zn}, \mathrm{Mo}$ - V и Ni - Na. При этом Ba, La и V не имеют значимых корреляционных связей ни с одним из элементов. Такие геохимические особенности разрезов различных частей и горизонтов КВ одной и той же трубки показывают, что для полной характеристики профилей переменного состава (кимберлитов) необходимо изучать несколько разрезов, вскрывающих элювиальные профили в различных частях. Это позволяет получать данные как для отдельных участков, так и в целом для всего объема, подвергшегося выветриванию геологического тела.

Существенно иная КВ кимберлитов отмечена на трубке Дачная. Границу между плотными и выветрелыми кимберлитами здесь с некоторой долей условности можно провести примерно на глубине 50 м (рис.3, б). Указанное тело перекрыто толщей мезозойских осадочных пород (мощностью до 18 м). Для кимберлитов трубки характерна слабая сцементированность (за исключением участков первичной карбонатизации); они сравнительно легко распадаются в воде на составляющие компоненты. Однако полная дезагрегация большинства изученных образцов наступает только после 1-2-часового кипячения (нередко в кислой среде). В условно выделенной части выветрелых кимберлитов четкой зональности не наблюдается.

Представляется возможным независимо от положения пород в разрезе выделить кимберлиты разных стадий выветривания:

а) слабо выветрелье породы, полностью сохраняющие структуру исходного кимберлита; в воде они обычно сравнительно легко распадаются на составные части;

б) умеренно вылетрельле породы; реликтовые структуры кимберлитов и присутствующих в них различных включений обычно сохраняются, но часто в различной степени затушевываются вторичными железисто-глинистыми образованиями; увеличение в таких участках содержания псаммито-алевритового компонента делает состав элювия более однородным, чем в слабо выветрелых пород;

в) сильно выветрелье породы, первичная материнская структура в которых практически не отмечается. Обычно поро- 
ды этой стадии выветривания представлены слегка комковатыми, пропитанными гидроксидами железа глинистыми образованиями. Цвет их из-за неравномерного распределения железистых соединений изменяется от серовато-желтого до коричневого разных оттенков.

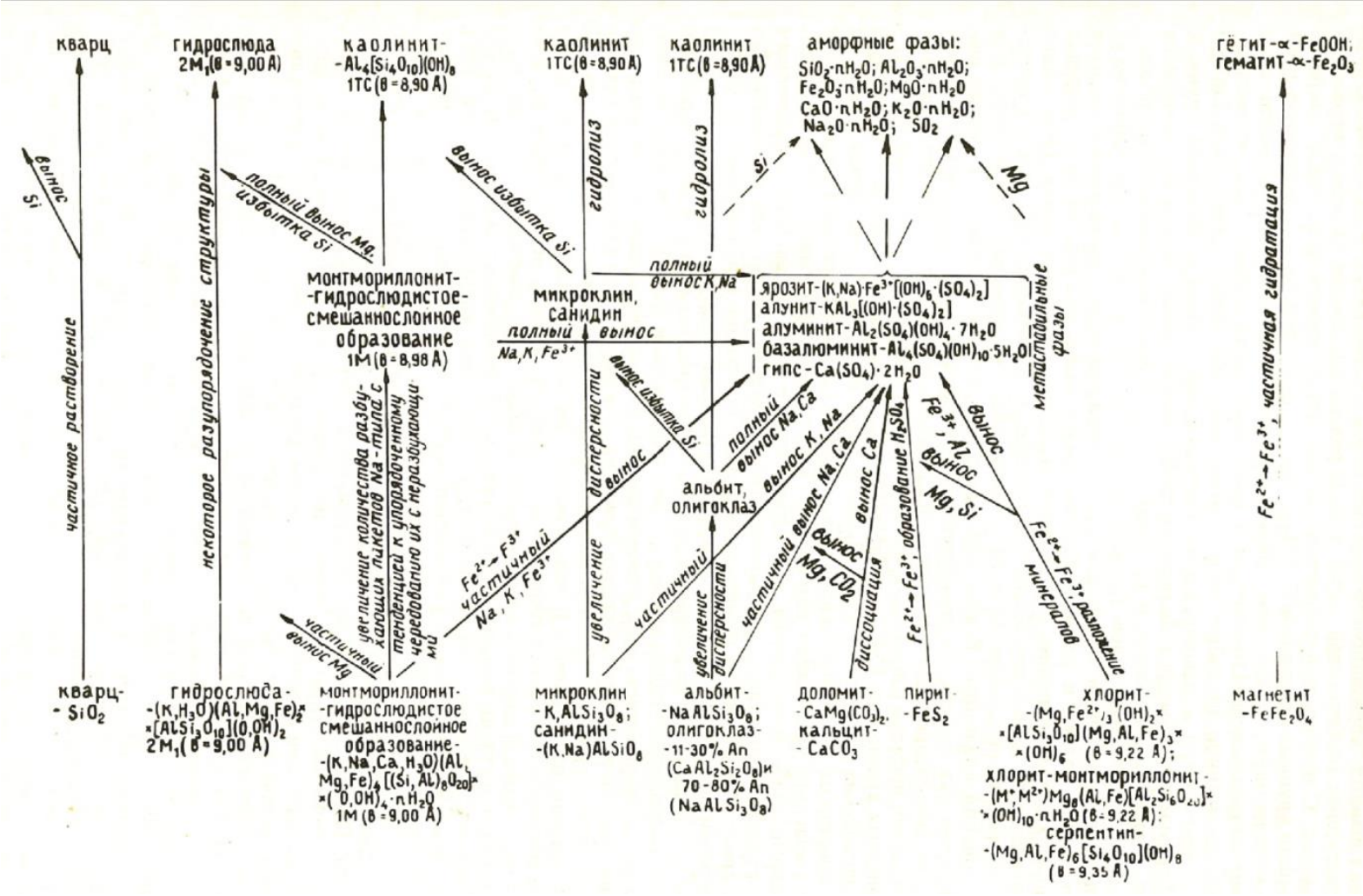

Рис. 4. Схема преобразования минералов в коре выветривания кимберлитов

Сильно выветрелые породы встречаются преимущественно в верхах разрезов, но иногда отмечаются и на значительных глубинах. Это объясняется нами избирательным характером выветривания, зависящим от многих факторов (в первую очередь от трещиноватости пород). В таких разрезах нет резкого изменения физических свойств пород в процессе выветривания. В частности, плотность $(2,62-2,74$

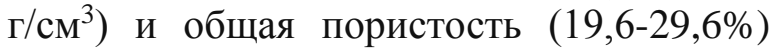
изменяются в них слабо. Большая часть минералов легкой фракции обычно замещена глинисто-железистыми агрегатами. В тяжелой фракции преобладают гранаты и пикроильменит. Другие реликтовые минералы (хромдиопсид, хромшпинелиды и др.) отмечены в подчиненном количестве и распределены довольно неравномерно. В целом их концентрации значительно уменьшаются в выветрелых образованиях диатремы (глубины 18-50 м), где резко возрастает роль аутигенных минералов (пирита, гидроксидов железа, а в верхних частях профилей - и сидерита). Среди гранатов преобладают фиолетовые пиропы. Состав фракции мельче 0,001 мм довольно близок к описанному выше в КВ трубки имени ХХШ сьезда КПСС. Для КВ трубки Дачная характерна (рис.3, б) незначительная подвижность основных петрогенных элементов. Исключение составляет кремнезем, которому свойственны существенные колебания концентрации (от 10,56 до $88,89 \%$ ), что связано с неоднородностью пород данного разреза (переменное содержание пелитоморфных образований кварца). Изменения по профилю (рис. 3, б) концентраций (в \%) $\mathrm{FeO}$ $(0,97-21,31), \mathrm{MgO}(2,44-15,75), \mathrm{CaO}(1,20-$ $31,44)$ и $\mathrm{CO}_{2}(7,73-25,42)$ связаны (таблица; рис.4) с разрушением в процессе выветривания серпентина, кальцита и доломита, а также образованием в верхних горизонтах сидерита. В значительно небольших пределах изменяются концен- 
трации $\mathrm{Al}_{2} \mathrm{O}_{3}(4,06-9,18 \%)$ и $\mathrm{Fe}_{2} \mathrm{O}_{3}(2,00$ $3,71)$. Постоянное присутствие в КВ $\mathrm{K}_{2} \mathrm{O}$ $(1,94-2,75 \%)$ вызвано значительным содержанием в пелитовой составляющей монтмориллонит-гидрослюдистых смешанослойных образований. Ряд подвижности петрогенных компонентов имеет следующий вид: $\mathrm{CaO}>\mathrm{FeO}>\mathrm{TiO}_{2}>$ $\mathrm{Al}_{2} \mathrm{O}_{3}>\mathrm{Na}_{2} \mathrm{O}$. Довольно монотонно распределены по профилям этого типа КВ главнейшие акцессорные элементы. Общее увеличение концентрации свойственно только $\mathrm{Be}, \mathrm{Mn}$ и $\mathrm{B}$, а уменьшение $-\mathrm{Sr}$. Выделены следующие устойчивые парагенетические ассоциации элементов: $\mathrm{Be}-$ $\mathrm{V}-\mathrm{Ga}-\mathrm{P}, \mathrm{Mn}-\mathrm{Co}-\mathrm{B}, \mathrm{Cu}-\mathrm{Nb}, \mathrm{Na}-\mathrm{Cr}$ и $\mathrm{Pb}-\mathrm{Cs}$.

Трубка Таёжная выполнена в основном кимберлитовой брекчией, верхние горизонты которой (до глубины примерно 2728 м) сильно изменены и представляют собой типичную элювиальную КВ. Юговосточная часть трубки перекрыта маломощной (первые метры) толщей осадочных пород нижней юры. Границы между выветрелыми и сравнительно плотными кимберлитами проходят (рис.3, в) на разных глубинах трубки, от 50-60 м в приконтактовых и до 20-25 м в центральных частях. Вверх по разрезу выветрелой толщи цвет кимберлита изменяется от голубовато-серого, серого, серовато- и голубовато-зеленого до желтовато-коричневого и красновато-бурого. КВ этих кимберлитов изучена нами по разрезу скв.74/1, а также по нескольким искусственным обнажениям в северо- и юго-восточной частях трубки. В процессе выветривания постепенно уменьшается средняя плотность (от

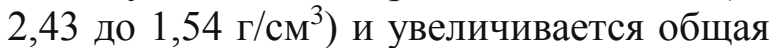
пористость пород (от 12,05 до 43,68\%). Увеличивается также количество пелитовой составляющей, отчего содержание фракции мельче 0,01 мм в верхних частях профилей достигает 88,25\%. Наибольшие выходы тяжелой фракции (до 48,3\%) отмечены в гранулометрических классах 1,0-0,5 и 0,5-0,25 мм, тогда как в более мелких размерах её содержание редко превышает первые проценты. В легкой фракции образований данной КВ, как и в аналогичных разрезах других трубок, доминируют глинисто-железистые $\quad(27,0-$ $47,1 \%)$, глинисто-карбонатные $\quad(10,9-$ $23,2 \%$ ) и глинисто-кремнистые (до $27,8 \%$ ) агрегаты. Содержание кварца в целом невелико. Относительно увеличивается его количество (до 32,3\%) в верхних горизонтах профиля. Содержание полевых шпатов обычно не превышает $10 \%$. Тяжелая фракция обогащена ильменитом (44,761,6\%). Содержание неустойчивых (слюды, пироксены, амфиболы) и умеренно устойчивых (группа эпидота и апатит) минералов не превышает в сумме $20 \%$. Отмечаются незначительные колебания в распределении весьма устойчивых минералов тяжелой фракции - гранатов $(7,8$ $12,6 \%)$, турмалина $(0,8-3,9 \%)$ и циркона (4,3-9,3\%). В составе аутигенного комплекса минералов доминируют гидроксиды железа $(34,7-50,0 \%)$, пирит $(23,1-$ $35,9 \%)$ и барит $(23,8-29,4 \%)$. Для данной КВ характерны невысокая подвижность основных элементов и отсутствие резких колебаний в содержании преобладающих компонентов (рис.3, в). Ряд подвижности химических компонентов с тенденцией к накоплению характеризуется следующей последовательностью (в $\left.\Gamma / \mathrm{cm}^{3}\right): \mathrm{K}_{2} \mathrm{O}$ (от 0,0059 до 0,0348 ), $\mathrm{Al}_{2} \mathrm{O}_{3}$ (от 0,0376 до 0,0948 ), $\mathrm{Fe}_{2} \mathrm{O}_{3}$ (от 0,0585 до 0,1039). В общем балансе вещества прослежен вынос (в $\Gamma / \mathrm{cm}^{3}$ ) таких элементов, как $\mathrm{Cr}_{2} \mathrm{O}_{3}$ (от 0,0062 до 0,0013), $\mathrm{CaO}$ (от 0,06309 до 0,1813 ), $\mathrm{CO}_{2}$ (от 0,4117 до 0,1679 ) и $\mathrm{P}_{2} \mathrm{O}_{3}$ (от 0,0557 до 0,0052). Методом факторного анализа выделяются следующие ассоциирующие группы химических компонентов: $\mathrm{Cr}_{2} \mathrm{O}_{3}-\mathrm{CaO}-\mathrm{Na}_{2} \mathrm{O}-\mathrm{P}_{2} \mathrm{O}_{5}-\mathrm{CO}_{2}-$ $\mathrm{CO}_{2}-\mathrm{F}$ и $\mathrm{Fe}_{2} \mathrm{O}_{3}-\mathrm{FeO}-\mathrm{MgO}-\mathrm{Co}-\mathrm{NiO}$.

В строении трубки Амакинская также преобладают кимберлитовые брекчии. В верхних горизонтах диатремы отмечена КВ (мощностью до 20 м), перекрытая четвертичными отложениями (до 5 м). Наиболее изменены кимберлиты в приконтактовой части тела. В зависимости от степени преобразования окраска их пород изменяется от голубовато-серой (у плот- 
ного кимберлита) до серовато-желтой и желтовато-бурой (у выветрелых образований). Наиболее интенсивно изменены кимберлитовые породы в верхних горизонтах трубки, где они превращены в рыхлые желтовато-бурые глинистые образования. Только в отдельных обохренных обломках встречаются реликты структур исходных пород. Глубина залегания затронутых выветриванием кимберлитов иногда достигает 45-50 м. Однако условную границу КВ кимберлитов можно провести на глубине примерно 25 м. Комплекс минералов легкой, тяжелой и глинистой фракций довольно близок к другим трубкам региона. Маломощная КВ (первые метры) развита также на кимберлитах трубки Интернациональная, где не отмечено глубокой переработки исходных материнских пород. Изучение вещественного состава по разрезу скважин 109 и 110 м (а также по канаве №-1) показало, что выветриванию подвергались плотные серые и голубовато-серые кимберлитовые брекчии. Вверх по разрезу за счет увеличения концентрации гидроксидов железа окраска пород изменяется от желтовато-серой, зеленовато-желтой и желтовато-бурой. Четких следов изменения первичных минералов кимберлитов при выветривании здесь не отмечается. Только флогопит полностью изменен и замещен $\mathrm{Fe}-\mathrm{Mg}$ хлоритом. В составе пелитовой составляющей (как и в других диатремах района) доминируют монтмориллонит и монтмориллонит-гидрослюдистое смешанослойное образование, ассоциирующие с переменным (и в целом небольшим и полностью отсутствующим в отдельных участках) количеством гидрослюды и тонкодисперсного слабо окристаллизованного хлорита.

В Далдыно-Алакитском алмазоносном районе КВ кимберлитов изучена нами на диатремах Юбилейная, Сытыканская и Молодость, несколько отличающихся как по геологическому строению, так и по особенностям состава и локализации продуктов выветривания. КВ на кимберлитах трубки Юбилейная зафиксирована в виде небольшого останца мощностью 8-13 м в восточной части тела и вскрыта скв.231, 234 и др. Перекрывается элювиальная толща мощной (до 45-48 м) толщей осадочных пород верхнего палеозоя. Исходные, не выветрелые породы трубки Юбилейная представлены зеленовато-серой, серовато-зеленой, участками желтоватосерой кимберлитовой брекчией (глубины ниже 68 м). В породах содержится большое количество включений (преимущественно терригенно-карбонатных пород), а также порфировых выделений серпентина и слюдистых образований. Преобладающая масса породы имеет серпентинкарбонатный состав. Вверх по разрезу обычно увеличивается трещиноватость пород. По трещинам кимберлиты изменяются более интенсивно. Трещины заполняются вторичными глинисто-железистыми продуктами, а псевдоморфозы серпентина представлены вторичными образованиями, окрашенными в различные оттенки бурого цвета и нередко характеризующимися лучистым строением. В верхней части разреза структурные особенности материнских пород практически не сохраняются (отмечаются лишь в редких обломках). Эти горизонты КВ (глубины примерно 48-52 м) сложены сероватозелеными и желтовато-бурыми глинистыми образованиями, содержащими большое количество темно-коричневых выделений (преимущественно гётита и гидрогётита). В целом при выветривании кимберлитов трубки Юбилейная уменьшаются размеры породообразующих компонентов, что приводит к резкому (до 91\%) увеличению пелитовой составляющей. Следует отметить, что значительное содержание фракции мельче 0,01 мм зафиксировано и в некоторых более глубоких горизонтах (глубины 53-56,5 м и др.), что связано с более интенсивным изменением кимберлитов на участках сильной трещиноватости пород $[12,13]$. В составе породообразующего комплекса доминируют карбонаты (до $87,8 \%$ легкой фракции) или глинистокарбонатные агрегаты (до 93,3\%). В отдельных участках разреза несколько по- 
вышены концентрации слюд (до 29,1\%) и слюдисто-глинистых образований (до $27,7 \%$ ). Значительные количества кварца (до 13,9\%) и полевых шпатов (до 17,2\%) отмечены только в единичных изученных образцах. В легкой фракции доминируют глинистые, слюдисто- и кремнистоглинистые, глинисто-железистые и карбонатно-глинистые агрегаты. Присутствуют также выделения желтовато- и краснобурого, зеленовато-желтого, бурого и других цветов с характерной пелитоморфной структурой. В целом описываемая КВ характеризуется незначительными колебаниями содержаний минералов тяжелой фракции. Исключение составляют только горизонты, обогащенные аутигенными тяжелыми минералами, зафиксированными почти на контакте с перекрывающими осадочными толщами и на глубине примерно 58 м, что соответствует границе выветрелых и слабо измененных кимберлитов. При этом следует отметить, что тя-

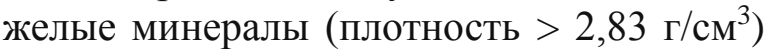
довольно равномерно распределены в гранулометрических классах частиц измененных кимберлитов (от 2,0 до 0,05 мм). Комплекс первичных минералов тяжелой фракции в целом резко обогащен гранатами (до 89,3\%), довольно неравномерно распределенными по разрезу. Вторым по распространенности первичным минералом является ильменит (до 29,3\%) и продукты его изменения (до 49,7\%). Концентрация умеренно устойчивых (апатит и группа эпидота) и других (кроме гранатов) весьма устойчивых (турмалин, циркон, рутил, сфен и др.) минералов редко превышает первые проценты. Морфологически минералы рассматриваемой трубки довольно близки к минералам других трубок СП. Постоянно присутствуют аутигенные минералы, нередко составляющие более половины обьема фракции. Здесь резко доминируют пирит (до 92,5\%) и гидроксиды железа (до 99,1\%). Сидерит и барит имеют подчиненное значение. В пелитовой составляющей преобладает монтмориллонит, ассоциирующий с переменным содержанием неупорядоченных монтмориллонит-гидрослюдистых смешанослойных образований. Содержание флогопита и гидрослюды местами составляет до 50\% всех слоистых силикатов. Флогопит обычно значительно изменен и замещен вторичными образованиями хлорита (а иногда и вермикулита), резко доминирующими в отдельных горизонтах (до 80\% фракции мельче 0,01 мм). Для образований данной КВ характерны (рис.3, г) почти линейные отрицательные тренды распределения $\mathrm{SiO}_{2}$ и $\mathrm{MgO}$, положительные тренды распределения $\mathrm{CaO}$ и $\mathrm{CO}_{2}$, а также общее увеличение концентраций железа и частично кремнезема. Наибольшая изменчивость свойственна $\mathrm{Al}_{2} \mathrm{O}_{3}$ и $\mathrm{SO}_{3}$. Ряд подвижности элементов с тенденцией к общему накоплению $\left(\Gamma / \mathrm{cm}^{3}\right)$ : $\mathrm{SO}_{3}$ (от 0,0085 до 0,0188), $\mathrm{FeO}$ (от 0,0711 до 0,1470$)$ и $\mathrm{TiO}_{2}$ (от 0,0211 до 0,0424 ). Тенденция к выносу зафиксирована для

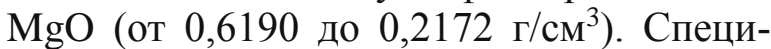
фичны для профиля КВ кимберлитов трубки Юбилейная корреляционные связи между основными петрогенными компонентами. Определены и прослежены следующие ассоциации оксидов: $\mathrm{TiO}_{2}-\mathrm{FeO}-$ $\mathrm{CoO}-\mathrm{NiO}, \mathrm{CaO}-\mathrm{CO}_{2}$ и $\mathrm{K}_{2} \mathrm{O}-\mathrm{SO}_{3}-\mathrm{F}-$ $\mathrm{P}_{2} \mathrm{O}_{5}$. Последняя ассоциация иногда дополняется $\mathrm{Al}_{2} \mathrm{O}_{3}$ и $\mathrm{Fe}_{2} \mathrm{O}_{3}$.

Блоковым распространением слоя выветрелого кимберлита характеризуется КВ на трубке Cытыланская. На большей части диатремы развит древний (допермский) элювий кимберлитов мощностью от 0,4 до 2,4 м, представляющий корни КВ. Продуктом древнего корообразования является развитие по серпентину монтмориллонита $\mathrm{Mg}$ и $\mathrm{Mg}$-Al-состава [11, 12, 32]. Судя по изученным разрезам (скв.98 и 112), гранулометрический состав слабо измененных кимберлитов верхних горизонтов диатремы характеризуется значительной изменчивостью. К верхам разрезов увеличивается количество пелитового компонента, наибольшее содержание которого (до 60-70\%) отмечено в образованиях верхних горизонтов (примерно до глубины 95 м). Одновременно резко уменьшается в этом направлении содер- 
жание более крупных частиц (крупнее 5 мм). В тяжелом концентрате доминируют рудные минералы. Содержание пикроильменита во фракциях 0,25-0,1 и 0,1-0,05 мм из верхних горизонтов изменяется в пределах 35-64\%, несколько понижаясь в верхних частях трубки (до глубины примерно 95 м). Наибольшая концентрация гранатов (до 25\% всех первичных минералов) зафиксирована во фракции 0,1-0,05 мм, а во фракции 0,25-0,1 мм их количество несколько уменьшается. Это объясняется присутствием многих трещиноватых зерен гранатов, легко рассыпающихся при выветривании на осколки крупноалевритовой (0,1-0,05 мм) размерности. Особенно резкие (от 3 до 19\%) колебания содержания гранатов отмечены в самых верхних частях разрезов. Доминирующее положение (иногда 100\%) в аутигенном комплексе минералов тяжелой фракции (классов 0,25-0,1 и 0,1-0,05 мм) занимают гидроксиды железа. Отмечено также значительное (до 30\%) количество тонкокристаллического пирита. Размеры его кристаллов и их обломков не превышают обычно 0,1 мм, чем объясняется его отсутствие во фракции 0,25-0,1 мм изученных образцов. В этой фракции в отдельных пробах из верхних частей разреза отмечено значительное (до 10\%) количество барита. Следовательно, верхние горизонты трубки Сытыканская (примерно до глубины 95 м) подверглись процессам гипергенного преобразования, приведшим к формированию слабо выраженной КВ кимберлитов. Судя по составу пелитовой составляющей (преобладание монтмориллонита, ассоциирующего с неупорядоченными монтмориллонит-гидрослюдистыми смешанослойными образованиями), а также внешнему облику пород и характеру вторичного минералообразования, формирование этой элювиальной толщи остановилось на начальных стадиях зоны дезинтеграции и начального гидролиза.

Большая часть кимберлитовой трубки Молодость перекрыта породами трапповой формации - туфогенными образованиями и долеритами. Примерно 15\% трубки обнажается в поле развития силурийских образований и перекрывается каменноугольно-пермскими отложениями. Верхи диатремы представляют собой типичную элювиальную КВ мощностью до 10-15 м. Здесь подвергались выветриванию кимберлитовые брекчии. Они обычно слабо сцементированы и окрашены в различные серые тона (темные, зеленые и бурые). Среди них довольно много карбонатных и терригенно-карбонатных включений, в различной степени выветрелых. Породы разбиты многочисленными прожилками, выполненными белесыми и серовато-белыми образованиями гипса. Мощность таких прожилков 0,1-3,0 мм. Довольно характерны здесь выделения пирита (размером до 3-5 мм в поперечнике), гнезда и прожилки кальцита и проявления битумов, которые нередко встречаются совместно. Попадаются также измененные ксенолиты метаморфических пород и многочисленные автолиты, обычно четко отличающиеся от вмещающих пород по цвету. КВ трубки Молодость в отдельных разрезах характеризуется различной выветрелостью материала. Это подчеркивается прежде всего повышенным содержанием мелких частиц - 0,1 0,05 мм (до 45\%) и мельче 0,01 мм (до $58 \%$ ). Отмечается закономерность увеличения концентраций таких частиц вверх по разрезу. Четкого распределения минералов легкой и тяжелой фракции не наблюдается. Отмечено только некоторое изменение в верхах профилей содержания флогопита (замещенного нередко хлоритом) и ильменита (увеличивается концентрация лейкоксена). Несколько увеличиваются также в верхних горизонтах содержания гидроксидов железа (гётит) и гематита, что придаёт этим элювиальным образованиям желтовато- и красно-бурую окраску. Характерной особенностью профилей этой КВ являются высокие исход-

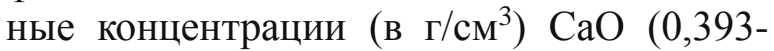
$0,473), \mathrm{MgO}(0,474-0,534)$ и $\mathrm{CO}_{2}(0,295-$ $0,375)$, что связано с преобладанием серпентина, кальцита и доломита [12]. В частично дезинтегрированных породах (глу- 
бина 23-25 м) также значительно увеличиваются концентрации $\mathrm{CaO}$ (до 0,628 г/ $\mathrm{cm}^{3}$ ) и $\mathrm{CO}_{2} \quad\left(0,463 \quad \Gamma / \mathrm{cm}^{3}\right)$ и соответственно

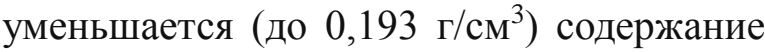
$\mathrm{MgO}$. Это связано в основном с выщелачиванием и разрушением доломита, а также с развитием вторичного кальцита, плотно цементирующего отдельные участки пород. Содержание $\mathrm{SiO}_{2}$ несколько увеличивается (до 0,618 г/ $\mathrm{cm}^{3}$ ) только в верхних частях профиля. Отмечено здесь также возрастание концентрации $\mathrm{P}_{2} \mathrm{O}_{5}$ (до 0,024 г/ $\left.\mathrm{cm}^{3}\right)$. Наиболее четкую тенденцию к накоплению в разрезе показывают (в

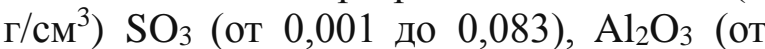
0,085 до 0,142 ) и $\mathrm{Fe}_{2} \mathrm{O}_{3}$ (от 0,073 до 0,130 ). В целом для описываемого профиля выветривания характерна довольно слабая взаимосвязь отдельных петрохимических элементов, что в значительной мере объясняется неоднородностью описываемого разреза. Тесная корреляционная связь наблюдается только между $\mathrm{CaO}-\mathrm{CO}_{2}$, $\mathrm{SiO}_{2}-\mathrm{Fe}_{2} \mathrm{O}_{3}, \mathrm{~K}_{2} \mathrm{O}-\mathrm{P}_{2} \mathrm{O}_{5}, \mathrm{FeO}-\mathrm{SO}_{3}$ и $\mathrm{Na}_{2} \mathrm{O}$ - F. «Малые» элементы относительно монотонно распределены по описываемому профилю. Тенденцию к общему накоплению проявляет только V. Отмечено резкое снижение концентраций $\mathrm{Sc}, \mathrm{Ni}$ и $\mathrm{Ba}$ даже в плотном неизмененном кимберлите (глубины 50-100 м). Наиболее четко выделяется только устойчивая парагенетическая ассоциация $\mathrm{Sc}-\mathrm{Ba}-\mathrm{Ni}-\mathrm{Cr}$. B остальных пробах также довольно четко выражены корреляционные связи $\mathrm{Sc}$ и $\mathrm{Ni}$ с $\mathrm{V}$.

Таким образом, полученные в результате комплексных исследований закономерности минералого-геохимического изменения кимберлитовых пород в результате действия гипергенных процессов показали их существенные отличия от аналогичных элювиальных продуктов, развитых на породах другого состава (терригеннокарбонатные породы, долериты, туфы и туфогенные образования) в этих же алмазоносных регионах. В пределах изученных алмазоносных районов СП отмечены кимберлитовые трубки с развитой КВ, причем интенсивность её развития связа- на не только с климатическими особенностями, но и со структурной позицией участка, где находится диатрема. На большинстве изученных нами кимберлитовых диатрем в верхах разрезов были развиты охристо-глинистые элювиальные толщи, но впоследствии в ряде случаев они были частично смыты. Для легких фракций элювия кимберлитов характерно присутствие бледно-оливковых и желтовато-зеленых чешуек флогопита и продуктов его изменения (хлорита, а иногда и вермикулита), обломков серпентина, а также глинисто-карбонатных агрегатов, состоящих преимущественно из смеси глинистых минералов, кальцита и доломита. Особый интерес представляет вопрос о типоморфных особенностях минераловпарагенетических спутников алмаза (пиропа, пикроильменита, хромшпинелидов и др.) из кимберлитов различной степени изменения. Для интенсивно химически измененных кимберлитов довольно характерны зерна пиропа, корродированные по кубоидному типу, с примазками (белесой рубашкой). Как для плотных, так и для частично измененных гипергенными процессами кимберлитов довольно характерны зерна пиропов с келифитовой каймой, а также выделения пикроильменита с белесой лейкоксеновой оболочкой. Внешняя поверхность таких пиропов обычно покрыта бугорчатыми образованиями, повторяющими рельеф зерна под келифитовой каймой, которая часто имеет радиально-лучистое строение. Между основанием каймы и поверхностью пиропа (как и по трещинам в нем) отмечаются пелитоморфные новообразования. Толщина каймы различная: от тонкой, плохо выраженной, до мощной, практически полностью замещающей пироп. Наиболее значительные келифитовые каймы встречаются на фиолетово-красных пиропах. Сложенные механически неустойчивыми минералами келифитовые каймы легко истираются при переносе минерала в водной среде или растрескиваются по направлению волокон. Трещиноватость пиропов и слабая связь с ними келифитовых кайм способ- 
ствуют быстрому разрушению их в процессе транспортировки. В результате такие каймы сохраняются на пиропах не далее первых сотен метров, редко первых километров путей миграции. Поэтому реликты келифитовой каймы на пиропах надежный признак близости коренного источника. Этим оправдан интерес к изучению особенностей поведения келифитовых кайм в процессе выветривания кимберлитов. Направление вектора выветривания кимберлитов на вариационной LM/OK-диаграмме [31] занимает промежуточное положение между полем терригенно-карбонатных образований и пород основного состава, т.е. в продуктах их выветривания с одинаковой вероятностью может идти образование и оксидов $\mathrm{Al}$, и каолинита. Свойственный слюде в кимберлитах политип $1 \mathrm{M}$ обусловливает, как менее устойчивый при выветривании, сравнительно более быстрое накопление в продуктах его диоктаэдризации $\mathrm{Al}$, чем выветривание слюды $2 \mathrm{M}_{1}$ в терригеннокарбонатных породах.

В глинистой составляющей продуктов выветривания кимберлитов кроме содержащихся в легкой фракции серпентина, хлорита и вермикулита присутствуют также монтмориллонит, неупорядоченное монтмориллонит-гидрослюдистое смешанослойное образование и гидрослюда. В октаэдрических сетках структуры разбухающих минералов содержатся главным образом $\mathrm{Fe}^{3+}$ и Al. Начиная с нижних горизонтов коры выветривания кимберлитов в изученных профилях доминирует серпентин, характеризующийся структурными типами А и В. При этом для частиц новообразованного политипа (А) в начале изменений характерна округлая глобулярная форма, причем глобулы обычно образуются на острых гранях других минералов. На некоторых участках отдельные глобулы сочленяются в вытянутые червеподобные сростки. Вверх по профилям выветривания происходит укрупнение как частиц новообразованного серпентина, так и свойственных им сростков, причем у отдельных кристаллов появляется в этом случае псевдогексагональная огранка, a сам серпентин практически полностью переходит в более устойчивую в гипергенных условиях модификацию А. Это показывает, что уже на ранних стадиях выветривания кимберлитов изменение серпентина связано в основном с его перекристаллизацией, сопровождающейся политипными превращениями. В целом морфологические выделения серпентина в породах, не затронутых выветриванием, существенно отличаются от его форм в продуктах гипергенного изменения кимберлитов и родственных им пород. Одновременно с этим слоистые минералы триоктаэдрического типа либо разлагаются (Mg-, Fe-Mg-хлориты), либо частично преобразуются в диоктаэдрические разности (как флогопит в гидрослюду). Эти процессы обуславливают значительное повышение пористости и проницаемости пород, что определяет последовательное увеличение в их обьеме открытой поверхности, контактирующей с флюидами, и скорости дренирования последними выветривающихся горизонтов. Минеральный состав новообразований и распределение по профилям значений $\mathrm{pH}(9,46-7,10)$ и $\mathrm{Eh}$ (328-190) позволяют утверждать, что рассматриваемая стадия выветривания кимберлитов соответствует щелочному типу. Изученные нами разрезы можно отнести к типу остаточных локальных КВ, находящихся на стадии начальной гидратации исходных минералов и выщелачивания наименее устойчивых компонентов.

Сложный многокомпонентный состав исходных пород в древних КВ кимберлитов СП, содержащий ди- и триоктаэдрические минералы, в структуре которых есть трех- и двухвалентные породообразующие элементы, обусловил замедленное преобразование первичного материала. В результате формирование разрезов КВ кимберлитов зачастую приостанавливалось на начальных стадиях. Развитие неполных профилей выветривания вызвано прежде всего слабым выносом двухвалентных катионов из структуры первичных минералов. Поэтому вновь возникающие фазы 
являются диоктаэдрическими и нередко сохраняют смешанный состав структурных катионов. Поскольку в продуктах выветривания преобладает пелитовая составляющая, важнейшим типоморфным признаком глинистых образований в КВ кимберлитов является содержание совместно с поликатионным монтмориллонитом значительного количества триоктаэдрического хлорита (пакеты $\delta$ и $\left.\delta^{\prime}\right)$, серпентина (структурные типы А и В) и в различной степени измененного флогопита, в том числе связанной с ними гидрослюды 1М. Для содержащихся в КВ кимберлитов монтмориллонит-гидрослюдистых смешанослойных образований также характерны специфические особенности, связанные с продуктами последовательной диоктаэдризации флогопита и их дальнейшей деградацией.

\section{Библиографический список}

1. Благулькина В.A. Петрохимические типы кимберлитов Сибири // Советская геология. 1969. №7. С.60-70.

2. Бобриевич А.П., Илупин И.П., Козлов И.Т. и $\partial p$. Петрография и минералогия кимберлитовых пород Якутии. М.: Недра, 1964. $192 \mathrm{c}$.

3. Василенко В.Б., Зинчук Н.Н., Кузнецова Л.Г. Петрохимические модели алмазных месторождений Якутии. Новосибирск: Наука, $1997.574 \mathrm{c}$.

4. Давыдов Ю.В., Мишнин В.М., Шамиина Э.А. Коры выветривания Ботуобинского района // Древние коры выветривания Якутии / ЯФ СО АН ССССР. Якутск, 1975. С.86-108.

5. Доусон Дж. Кимберлиты и ксенолиты в них. М.: Мир, 1983. 300 с.

6. Затхей Р.А., Зинчук Н.Н., Хмелевский В.А. Геохимические аспекты формирования кор выветривания кимберлитов (на примере одной из трубок Якутии) / ВИНИТИ. М., $1980.37 \mathrm{c}$.

7. Зинчук Н.Н. О минеральном составе келифитовых кайм на гранатах из кимберлитов // Зап. Всесоюз. мин. об-ва. 1981. Ч.110, вып.1. С.70-76.

8. Зинчук Н.Н. Типоморфные особенности продуктов выветривания различных пород
Западной Якутии в связи с проблемой поисков погребенных россыпей алмазов // Происхождение и размещение россыпей Якутии / ЯФ СО АН СССР. Якутск, 1983. C.94-102.

9. Зинчук Н.Н. Глинистые минералы в древних корах выветривания и продуктах их переотложения в континентальных толщах Западной Якутии // Глинистые минералы в литогенезе / МОИП. М., 1986. С. 5-19.

10. Зинчук Н.Н. Особенности состава и распределения слюдистых образований в кимберлитовых породах Якутии // Изв. вузов. Геология и разведка. 1991. №7. С. 58-66.

11. Зинчук Н.Н. Сравнительная характеристика вещественного состава коры выветривания кимберлитовых пород Сибирской и Восточно-Европейской платформ // Геология и геофизика. 1992. №7. С. 99-109.

12. Зинчук Н.Н. Коры выветривания и вторичные изменения кимберлитов Сибирской платформы (в связи с проблемой поисков и разработки алмазных месторождений) / Новосибир. гос. ун-т. Новосибирск, 1994. $240 \mathrm{c}$.

13. Зинчук Н.Н. Постмагматические минералы кимберлитов. М.: Недра, 2000. 538 с.

14. Зинчук Н.Н., Зуенко В.В., Харькив А.Д. Опыт петрохимического картирования кимберлитовых пород (на примере трубок Заполярная и Новинка Верхнемунского района, Якутия) // Геология и геофизика. 1991. №11. C.73-82.

15. Зинчук Н.Н., Котельников Д.Д., Борис Е.И. Древние коры выветривания и поиски алмазных месторождений. М.: Недра, 1983. $196 \mathrm{c}$.

16. Зинчук Н.Н., Котельников Д.Д., Соколов В.Н. Преобразование минерального состава и структурных особенностей кимберлитов Якутии в процессе выветривания // Геология и геофизика. 1982. №2. С.42-53.

17. Зинчук Н.Н., Мельник Ю.М., Серенко В.П. Апокимберлитовые породы // Там же. 1987. №10. C.66-72.

18. Зинчук Н.Н., Тараненко В.И., Борис Е.И. и $\partial p$. Коры выветривания бассейна р. Вилюй // Изв. АН СССР. Сер. геол. 1978. №8. C.108-112.

19. Зинчук Н.Н., Харькив А.Д., Мельник Ю.М., Мовчан Н.П. Вторичные минералы кимберлитов. Киев: Наукова думка, 1987. 282 c.

20. Казанский Ю.П. Выветривание и его роль в осадконакоплении. М.: Наука, 1969. 
$126 \mathrm{c}$.

21. Казаринов В.П., Бгатов В.И., Гурова Г.И. и др. Выветривание и литогенез. М.: Недра, 1969. $439 \mathrm{c}$.

22. Каштанов М.С. Кора выветривания на кимберлитах Сибирской платформы как источник глинозема при бокситообразовании // ДАН СССР. 1966. Т.163, №3. С.672675.

23. Куковский Е.Г. Превращение слоистых силикатов. Киев: Наукова думка, 1973. 103 с.

24. Маршинцев В.К. Вертикальная неоднородность кимберлитовых тел Якутии / СО АН СССР. Новосибирск, 1986. 239 с.

25. Михайлов Б.М. Рудоносные коры выветривания. Л.: Недра, 1986. 238 с.

26. Петров В.П. Основы учения о древних корах выветривания. М.: Недра, 1967. $343 \mathrm{c}$.

27. Рожков И.С., Харькив А.Д., Мельник Ю.М. Древняя кора выветривания кимберлитов трубки имени ХХШ сьезда КПСС (Якутия) // ДАН СССР. 1969. Т.188, №5. С.11301133.
28. Файнштейн Г.Х. Коры выветривания и их роль в россыпном рудообразовании осадочного чехла Сибирской платформы // Рудоносные коры выветривания. М.: Наука, 1974. C.271-277.

29. Харькив А.Д., Зинчук Н.Н., Крючков А.И. Коренные месторождения алмазов мира. М.: Недра, 1998. 555 с.

30. Харькив А.Д., Мельник Ю.М. Древняя кора выветривания кимберлитовых пород трубки имени ХХШ сьезда КПСС // Геология, петрография и минералогия магматических образований северо-восточной части Сибирской платформы. М.: Наука, 1970. C. 230-246.

31. Хитров В.Г., Зинчук Н.Н., Котельников Д.Д. Применение кластер-анализа для выяснения закономерностей выветривания пород различного состава // ДАН СССР. 1987. Т.296, №-5. С.1228-1233.

32. Шамшина Э.А. Коры выветривания кимберлитовых пород Якутии. Новосибирск: Наука, 1979. 150 с.

\title{
Specific Features of Structure and Composition of the Weathering Crust of Kimberlite Rocks
}

\author{
N.N. Zinchuk \\ Western-Yakutian Sientific Center of the Sakha Republic Academy of Sciences \\ 4/1 Lenin Str., Mirny 678170, Russia. E-mail: nnzinchuk@ rambler.ru
}

This article presents the regularities revealed by complex study of mineralogicalgeochemical alteration of kimberlites in hypergenetic conditions. In the most developed weathering crust strata, the significant transformation is observed for rock-forming minerals and for stable primary minerals as well. The content of olivine, pyroxene, pyrope sufficiently decreases at the upper part of weathered crust profiles, but the role of picroilmenite increases. Represented by layers of structural type A and B serpentine dominates in lower part of the weathering profiles. The rounded, globular grains are characteristic for the layers of primarily formed type A, which are also observed on grains of other more stable minerals. At early stages of kimberlites' weathering, alteration of serpentine is related to its recrystallization accompanied by polytypic transformation. At the same time, the laminated minerals of trioctahedral type either decompose (Mg- and Fe-Mg-chlorites), or partially covert into dioctahedral forms (phlogopite to hydromica, etc). These processes causes the significant increase of porosity and permeability of primary rocks. It leads to significant increase of surface open for contacting to pneumatolytic-hydrothermal fluids and weathered horizons drainage intensity. Mineral composition of secondary forms and distribution of $\mathrm{pH}$ and Eh values at eluvial profiles suggest that this stage of kimberlites' weathering corresponds to an alkaline type. Eluvial profiles discussed in the article may be referred to the type of the residual local weathering crusts at the stage of initial hydration of primary minerals and leaching of 
the less stable components.

Key words: weathering crusts, kimberlites, mineralogical-geochemical alterations, pneumatolytic-hydrothermal fluids, trioctahedral and dioctahedral minerals.

\section{References}

1. Blagulkina V.A. 1969. Petrokhimicheskie tipy kimberlitov Sibiri [Petrochemical types of kimberlites of Siberia]. Sovetskaya geologiya. 7:60-70. (in Russian)

2. Bobrievich A.P., Ilupin I.P., Kozlov I.T., et al. 1964. Petrografiya i mineralogiya kimberlitovykh porod Yakutii [Petrography and mineralogy of kimberlite rocks of Yakutiya]. Moskva, Nedra, p. 192. (in Russian)

3. Vasilenko V.B., Zinchuk N.N., Kuznetsova L.G. 1997. Petrokhimicheskie modeli almaznykh mestorozhdeniy Yakutii [Petrochemical models of diamond deposits of Yakutiya]. Novosibirsk, Nauka, p. 574. (in Russian)

4. Davydov Yu.V., Mishnin V.M., Shamshina E.A. 1975. Kory vyvetrivaniya Botuobinskogo rayona [Weathering crusts of Botuobinskiy rayon]. In Drevnie kory vyvetrivaniya Yakutii. Yakutsk, YaF SO AN SSSR, pp. 86108. (in Russian)

5. Dawson, J.B. 1980. Kimberlites and their xenoliths. Springer, Berlin, p. 252.

6. Zatkhey R.A., Zinchuk N.N., Khmelevskiy V.A. 1980. Geokhimicheskie aspekty formirovaniya kor vyvetrivaniya kimberlitov (na primere odnoy iz trubok Yakutii) [Geochemical aspects of the kimberlite weathering crusts formation (example of Yakutian pipe)]. Moskva, BINITI, p. 37. (in Russian)

7. Zinchuk N.N. 1981. O mineralnom sostave kelifitovykh kaym na granatakh iz kimberlitov [About the mineral composition of celyphitic edge of garnets from kimberlites]. ZVMO. 110(1):70-76. (in Russian)

8. Zinchuk N.N. 1983. Tipomorfnye osobennosti produktov vyvetrivaniya razlichnykh porod Zapadnoy Yakutii v svyazi s problemoy poiskov pogrebennykh rossypey almazov [Typomorphic features of weathering material of different rocks from Western Yakutiya in relation to the problem of diamond buried placers prospecting]. In Proiskhozhdenie i razmeshchenie rossypey Yakutii. Yakutsk, YaF SO AN SSSR, pp. 94-102. (in Russian)

9. Zinchuk N.N. 1986. Glinistye mineral v drevnikh korakh vyvetrivaniya i produktakh ikh pereotlozheniya $\mathrm{v}$ kontinentalnykh tolshchakh Zapadnoy Yakutii [Clay minerals in ancient weathering crusts and redeposition materials in continental strata of Western Yakutiya]. In Glinistye mineraly v litogeneze. Moskva, MOIP, pp. 5-19. (in Russian)

10. Zinchuk N.N. 1991. Osobennosti sostava i raspredeleniya slyudistykh obrazovaniy $\mathrm{v}$ kimberlitovykh porodakh Yakutii [Characteristics of composition and distribution of micaceous aggregates in Yakutian kimberlites]. Izvestiya VUZov. Geologiya i razvedka. 7:58-66. (in Russian)

11. Zinchuk N.N. 1992. Sravnitelnaya kharakteristika veshchestvennogo sostava kory vyvetrivaniya kimberlitovykh porod Sibirskoy i Vostochno-Evropeyskoy platform [Comparative characteristics of mineral composition of weathering crust of kimberlite rocks of the Siberian and East-European platforms]. Geologiya i geofizika. 7:99-109. (in Russian)

12. Zinchuk N.N. 1994. Kory vyvetrivaniya i vtorichnye izmeneniya kimberlitov Sibirskoy platformy (v svyazi s problemoy poiskov i razrabotki almaznykh mestorozhdeniy) [Weathering crusts and secondary alteration of kimberlites of Siberian Platform (in relation to problem of prospecting and development of diamond deposits)]. Novosibirsk, NGU, p. 240. (in Russian)

13. Zinchuk N.N. 2000. Postmagmaticheskie mineral kimberlitov [Post-magmatic minerals of kimberlites]. Moskva, Nedra, p. 538. (in Russian)

14. Zinchuk N.N., Zuenko V.V., Kharkiv A.D. 1991. Opyt petrokhimicheskogo kartirovaniya kimberlitovykh porod (na primere trubok Zapolyarnaya i Novinka Verkhnemunskogo rayona Yakutii) [A case study of petrochemical mapping of kimberlite rocks: Zapolyarnaya and Novinka pipes, Verkhnemunskiy rayon, Yakutiya]. Geologiya i geofizika. 11:73-82. (in Russian)

15. Zinchuk N.N., Kotelnikov D.D., Boris E.I. 1983. Drevnie kory vyvetrivaniya i poiski almaznykh mestorozhdeniy [Paleoweathering crusts and diamond deposits exploration]. Moskva, Nedra, p. 196. (in Russian)

16. Zinchuk N.N., Kotelnikov D.D., Sokolov V.N. 1982. Preobrazovanie mineralnogo sostava i 
strukturnykh osobennostey kimberlitov Yakutii $\mathrm{v}$ protsesse vyvetrivaniya [Transformaion of the mineral composition and structural characteristics of kimberlites of Yakutiya during weathering process]. Geologiya i geofizika. 2:42-53. (in Russian)

17. Zinchuk N.N., Melnik Yu.M., Serenko V.P. 1987. Apokimberlitovye porody [Apokimberlite rocks]. Geologiya i geofizika. 10:66-72. (in Russian)

18. Zinchuk N.N., Taranenko V.I., Boris E.I et al. 1978. Kory vyvetrivaniya basseyna $r$. Vilyuy [Weathering crusts of the Vilyuy River basin]. Izvestiya AN SSSR. Ser. Geol. 8:108112. (in Russian)

19. Zinchuk N.N., Kharkiv A.N., Melnik Yu.M., Movchan N.P. 1987. Vtorichnye mineral kimberlitov [Secondary minerals of kimberlites]. Kiev, Naukova Dumka, p. 282. (in Russian)

20. Kazanskiy Yu.P. 1969. Vyvetrivanie i ego rol v osadkonakoplenii [Weathering and its role in sedimentation]. Moskva, Nauka, p. 126. (in Russian)

21. Kazarinov V.P., Bgatov V.I., Gurova G.I. et al. 1969. Vyvetrivanie i litogenez [Weathering and lithogenesis]. Moskva, Nedra, p. 439. (in Russian)

22. Kashtanov M.S. 1966. Kora vyvetrivaniya na kimberlitakh Sibirskoy platformy kak istochnik glinozyoma pri boksitoobrazovanii [Weathering crust of kimberlites of Siberian Platform as an alumina source for bauxite formation]. DAN SSSR. 163(3):672-675. (in Russian)

23. Kukovskiy E.G. 1973. Prevrashchenie sloistykh selikatov [Transformation of the layered silicates]. Kiev, Naukova Dumka, p. 103. (in Russian)

24. Marshintsev V.K. 1986. Vertikalnaya neodnorodnost kimberlitovykh tel Yakutii [Vertical inhomogeneity of kimberlites bodies of Yakutiya]. Novosibirsk, SO AN SSSR, p. 239. (in Russian)

25. Mikhaylov B.M. 1986. Rudonosnye kory vyvetrivaniya [Ore bearing weathering crusts]. Leningrad, Nedra, p. 238. (in Russian)

26. Petrov V.P. 1967. Osnovy ucheniya o drevnikh korakh vyvetrivaniya [Fundamentals of the paleo-weathering crusts]. Moskva, Nedra, p. 343. (in Russian)

27. Rozhkov I.S., Kharkiv A.D., Melnik Yu.M. 1969. Drevnyaya kora vyvetrivaniya kimberlitov trubki imeni XXШ syezda KPSS (Yakutiya) [Paleo-weathering crust of kimberlites of pipe named after XXШ KPSS Congress (Yakutiya)]. DAN SSSR. 188(5):11301133. (in Russian)

28. Faynshteyn G.Kh. 1974. Kory vyvetrivaniya i ikh rol v rossypnom rudoobrazovanii osadochnogo chekhla Sibirskoy platformy [Weathering crusts and their role in placer ore formation of sedimentary cover of the Siberian Platform]. In Rudonosnye kory vyvetrivaniya. Moskva, Nauka, pp. 271-277. (in Russian)

29. Kharkiv A.D., Zinchuk N.N., Kryuchkov A.I. 1998. Korennye mestorozheniya almazov Mira [World diamond primary deposits]. Moskva, Nedra, p. 555. (in Russian)

30. Kharkiv D.A., Melnik Yu.M. 1970. Drevnyaya kora vyvetrivaniya kimberlitovykh porod trubki imeni XXШ syezda KPSS [Paleoweathering crust of kimberlite rocks of pipe named after ХХШ KPSS Congress]. In Geologiya, petrografiya i mineralogiya magmaticheskikh obrazovaniy severo-vostochnoy chasti Sibirskoy platform. Moskva, Nauka, pp. 230-246. (in Russian)

31. Khitrov V.G., Zinchuk N.N., Kotelnikov D.D. 1987. Primenenie klaster-analiza dlya vyyasneniya zakonomernostey vyvetrivaniya porod razlichnogo sostava [Application of cluster analysis for determination of mechanism of weathering of different rocks]. DAN SSSR. 296(5):1228-1233. (in Russian)

32. Shamshina E.A. 1979. Kory vyvetrivaniya kimberlitovykh porod Yakutii [Weathering crusts of kimberlite rocks of Yakutiya]. Novosibirsk, Nauka, p. 150. (in Russian) 